Paper

\title{
Anode Catalyst of Hybrid AuPd and Rare Earth Doped Cerium Oxide/Multi-Walled Carbon Nanotubes for Direct Formic Acid Fuel Cells
}

\author{
Hsuan-Ming KUNG ${ }^{1}$, Yuh-Jing CHIOU ${ }^{2}$, Hong-Ming LIN $^{1} *$, \\ Andrzej BORODZINSKI ${ }^{3}$, Leszek STOBINSKI ${ }^{4}$ and Chung-Kwei LIN $^{5}$ \\ ${ }^{1}$ Department of Materials Engineering, Tatung University, Taipei 104, Taiwan. \\ ${ }^{2}$ Department of Chemical Engineering, Tatung University, Taipei 104, Taiwan. \\ ${ }^{3}$ Institute of Physical Chemistry, Polish Academy of Sciences, Kasprzaka 44/52, 01-224 Warsaw, Poland. \\ ${ }^{4}$ Faculty of Materials Science and Engineering, Warsaw University of Technology, Woloska 141, 02-507 Warsaw, Poland. \\ ${ }^{5}$ The School of Dental Technology, Taipei Medical University, 110 Taipei, Taiwan.
}

Received November 8, 2015; Revised January 11, 2016; Accepted January 12, 2016

\begin{abstract}
For the direct formic acid fuel cells, anodic Pd catalyst has attracted considerable attention recently. In order to enhance the catalytic ability, conductivity, and prevent from the catalyst poisoning, the synthesis of Au-Pd solid solution phase decorated on Ir or Ru doped $\mathrm{CeO}_{2}$ modified MWCNTs substrate by polyol and synchrotron X-ray irradiation method were studied. The composition, structure and morphology were analyzed by XRD, SEM, TEM, TGA, and ICP, respectively. The hybrid AuPd/MOS/MWCNTs were not formed a single phase of AuPd in EG solution via polyol method but successfully synthesized in DI water solution by X-ray irradiation photochemical method at beam line $01 \mathrm{~A}$ in Taiwan synchrotron radiation research center. The electrochemical analysis of AuPd series electrocatalysts via polyol method, $\mathrm{AuPd} / \mathrm{Ru}_{\mathrm{x}} \mathrm{Ce}_{1-\mathrm{x}} \mathrm{O}_{2} / \mathrm{MWCNT}$ have the highest electro-oxidizing current density in cyclic voltammetry experiment. However, $\mathrm{Pd} / \mathrm{CeO}_{2} / \mathrm{MWCNTs}$ have the lowest potential in the maximum electro-oxidizing current density. The results of ECSA indicate the $\mathrm{AuPd} / \mathrm{Ru}_{\mathrm{x}} \mathrm{Ce}_{1-\mathrm{x}} \mathrm{O}_{2} / \mathrm{MWCNTs}$ have the highest electrocatalytic property. For the electrocatalysts synthesized via X-ray irradiation method (1A), AuPd/MWCNTs (1A) has the highest electro-oxidizing current density in cyclic voltammetry experiment meanwhile it has the lowest potential in the maximum electro-oxidizing current density. In addition, the results of ECSA indicate the $\mathrm{AuPd} / \mathrm{CeO}_{2} / \mathrm{MWCNTs}(1 \mathrm{~A})$ have the highest electrocatalytic property which AuPd/MWCNTs is almost matched with. Also, the results indicate $\mathrm{Pd} / \mathrm{CeO}_{2} / \mathrm{MWCNTs}$ (polyol) have the highest stability up to $10 \mathrm{k}$ seconds with $250 \mathrm{~mA} / \mathrm{mg}$ Pd current density.
\end{abstract}

\section{KEY WORDS}

formic acid, fuel cell, $\mathrm{AuPd}, \mathrm{CeO}_{2}$, MWCNTs

\section{Introduction}

The advantages of employing direct formic acid fuel cells (DFAFCs) instead of direct methanol fuel cells (DMFCs) ${ }^{1,2)}$ are non-toxic, non-flammable, non-endangering, portable, smaller crossover flux of Nafion membrane penetration ${ }^{3)}$, and use of the high concentrations of fuel ( $15 \mathrm{M}$ vs. $3 \mathrm{M}, \mathrm{M}$ for molarity or mol/L) $)^{4)}$. These are the main reasons why formic acid fuel cells are gradually noted by most of researchers. Wherein, the catalyst of palladium replaces platinum because it can be used as good low-temperature catalyst of electrochemical oxidation in formic acid ${ }^{5)}$. Catalyst of palladium can also enhance its activity through metal, metal oxide ${ }^{6}$ or the double metal structure ${ }^{7,8}$. Compared to catalyst of platinum in formic acid fuel cells, the catalyst of palladium are cheaper

\footnotetext{
* Corresponding author Email: hmlin@ttu.edu.tw
}

and less poisoning effect. Furthermore, in order to increase the electro-catalytic characteristics, adjunction of gold composes with palladium to form solid solution, which can prevent the leaching of palladium catalyst in the sulfuric acid ${ }^{9}$.

Among the different metal oxides used as the support of palladium for CO oxidation, cerium oxide or ceria is one of the interesting metal oxides. Owing to the Mars-Van Krevelen reaction mechanism $^{10)}$, the cerium oxide provides excellent activity in the oxidation reaction. In oxygen-rich condition, $\mathrm{CeO}_{2}$ adsorbs oxygen and helps $\mathrm{CO}$ poisoned $\mathrm{Pd}$ activated: $2 \mathrm{Pd}-\mathrm{CO}_{\text {ads }}+\left(\mathrm{CeO}_{\mathrm{x}}\right)+\mathrm{O}_{2-\text { ads }} \rightarrow \mathrm{Pd}+2 \mathrm{CO}_{2 \text { gas }}+\mathrm{CeO}_{\mathrm{x}}$ In oxygen-lack condition, the lattice oxygen of ceria oxidizes $\mathrm{CO}$ : $\mathrm{Pd}-\mathrm{CO}_{\text {ads }}+\mathrm{O}_{\text {lattice }} \rightarrow \mathrm{Pd}+\mathrm{CO}_{\text {2gas }}$

A number of functions have been ascribed to ceria, including maintaining the dispersion of the catalytic metals ${ }^{11,12)}$ and stabilizing 
the surface area of the support ${ }^{13)}$. For MWCNTs modified by ceria, mesoporous structure of ceria and the advanced breaking of MWCNTs in the impregnation process may cause the increasing of surface area of MWCNTs. Due to a facile redox reaction cycle, ceria exhibits oxygen storage capacity and improves the $\mathrm{CO}$ and hydrocarbon oxidation. For CO oxidation, ceria has been found to lower the activation energy, increase the reaction rate and suppress the usual $\mathrm{CO}$ inhibition effect ${ }^{14)}$ which can decrease the poisoning effect. Besides, additional iridium or ruthenium may enhance the conductivity of metal oxide that will improve the performance of fuel cells ${ }^{15,16)}$.

Being a supporter of metal catalyst, $\mathrm{CeO}_{2}$ increases the dispersion of active metal. Frost ${ }^{17}$ and Golumski ${ }^{18)}$ pointed out that the load of precious metals can enhance the activity of $\mathrm{CeO}_{2}$, mainly because the metal catalyst provides electronic to stabilize oxygen vacancies. $\mathrm{Cao}^{19)}$ proposed the characteristics of variable valence are applied to electrodes, and $10^{-6}$ doping would allow the electronic conductivity increased by $1 \%$, which can be applied to the electrolyte. Scire et al. ${ }^{20)}$ also mention that the lattice oxygen of cerium oxide can be more easily moved to the surface to oxidize reactant at low temperature because the precious metal modified cerium oxide weaken the bond energy of Ce-O.

Ruthenium ( $\mathrm{Ru}$ ), like most of PGMs (platinum group metals), is fairly resistant to chemical attack. For fuels containing of $\mathrm{CO}$, or the methanol in DMFC, the presence of Ru in the binary catalyst of $\mathrm{Pt} / \mathrm{Ru}$ can effectively avoid $\mathrm{Pt}$ active site from poisoning issues ${ }^{21)}$ Small content of ruthenium was added to titanium to improve the corrosion resistance ${ }^{22}$. Iridium (Ir) shows similarities to platinum at high potential $\left(\mathrm{Ir} / \mathrm{Ir}^{3+} 1.16 \mathrm{~V}, \mathrm{Pt} / \mathrm{Pt}^{2+} 1.19 \mathrm{~V}\right)$. The Pt-Ir alloys can be used as the oxygen reduction electrocatalyst for polymer electrolyte fuel cells (PEFCs) and exhibited activity enhancement ${ }^{23)}$. In recent years, $\mathrm{Pt} / \mathrm{Ir}$ has been re-examined as a catalyst of alcohol oxidation. Tsaprailis and Birss ${ }^{24)}$ prepared Pt:Ir $=1.8: 1$ (mole ratio) by the sol-gel method in which activity is 3.5 or 5 times higher than the single Pt catalyst or Ir catalyst, respectively. It is also higher than commercial Johnson-Matthey PtRu (1:1).

Our research group has paid attention for years in the research of catalysts applying in direct liquid fuel cells by use of multiwalled carbon nanotubes (MWCNTs) as support to improve the metal dispersion and decrease nanometal particle sizes ${ }^{9,25-27)}$. These modifications about second metal and metal oxide show that the improvement of the electrocatalytic performance.

In this study, nano hybrid $\mathrm{CeO}_{2} / \mathrm{MWCNTs}, \mathrm{Ru}_{\mathrm{x}} \mathrm{Ce}_{1-\mathrm{x}} \mathrm{O}_{2} / \mathrm{MWCNTs}$ and $\mathrm{Ir}_{\mathrm{x}} \mathrm{Ce}_{1-\mathrm{x}} \mathrm{O}_{2} / \mathrm{MWCNTs}$ were prepared as supporters for electro catalysts by impregnation method. Then, Pd and AuPd nanoparticles were synthesized by polyol or photosynthesis method to deposit on the MO/MWCNTs supporters. These innovated hybrid nanomaterials developed in this study can enhance the electrocatalytic performances and contribute to the applications in direct formic acid fuel cells.

\section{Experiment}

Acid Treatment of MWCNTs: Multi-walled carbon nanotubes (Yong-Zhen Technomaterial CO., LTD, China, Purity with about $98 \% \sim 99 \%$.) of $3 \mathrm{~g}$, with $10-40 \mathrm{~nm}$ diameter and 5-20 $\mu \mathrm{m}$ length were put in $300 \mathrm{~mL}$ nitric acid (Merck, $65 \%$ ), ultrasonic for 1 hour, and heated to reflux (about $115^{\circ} \mathrm{C}$ ) for 9 hours. The acid treated products were then filtered, washed by deionized water (Mili-Q system, resistivity $18.2 \mathrm{M} \Omega \mathrm{cm}$ ) to $\mathrm{pH}$, and dried in a vacuum oven at $100{ }^{\circ} \mathrm{C}$. The procedure can remove graphitic particles, amorphous carbon and catalyst impurities as well as enhance the functional groups on the surface of nanotubes.

Preparation of Metal Oxide/MWCNTs: The weight percentage of $\mathrm{CeO}_{2}$ was set $20 \%$ on MWCNTs. And the doping amount of Ir or Ru was $0.1 \%$. In the beginning, the acid treated MWCNTs of $0.05 \mathrm{~g}$ were distributed in DI water via sonication for 1 hour. The solution of the precursor was added into the MWCNTs-suspension and then the mixture was heated with stirring to $65^{\circ} \mathrm{C}$ to evaporate solvent on mantle heater. When the solvent was completely removed, the product was calcined in an tube furnace under argon atmosphere with the heating rate of $5^{\circ} \mathrm{C} / \mathrm{min}$ heating to $700{ }^{\circ} \mathrm{C}$ and holding for one hour.

Preparation of Pd or AuPd/(Metal Oxide)/MWCNTs: The metal weight percentages were set to be $20 \% \mathrm{Pd}$ for $\mathrm{Pd} / \mathrm{MO} / \mathrm{MWCNTs}$ and $10 \% \mathrm{Pd} / 10 \% \mathrm{Au}$ for AuPd/MO/MWCNTs. There are two methods to prepare the composites.

Polyol method: The prepared Metal Oxide (MO)/MWCNTs of $0.035 \mathrm{~g}$ were added in $50 \mathrm{~mL}$ ethylene glycol (EG) and distributed via sonication for 1 hour. The solution of $\mathrm{Pd}$ or $\mathrm{Au}-\mathrm{Pd}$ precursors was added into the MO/MWCNTs-suspension, adjusted $\mathrm{pH}$ value to 12 by $\mathrm{KOH}$ solution, and heated with stirring to $155^{\circ} \mathrm{C}$ for 20 minutes on the mantle heater. The resulting black solid products of Pd or $\mathrm{AuPd} / \mathrm{MO} / \mathrm{MWCNTs}$ were centrifuged and washed with ethanol and distilled water. Finally, the black products were dried at $90^{\circ} \mathrm{C}$ in the air then annealed at $200{ }^{\circ} \mathrm{C}$ in $5 \%$ Hydrogen and $95 \%$ Argon for 1 hour. The prepared catalysts were denoted as $\mathrm{Pd} / \mathrm{MO} / \mathrm{MWCNTs}$. Synchrotron X-ray Irradiation Method: The same recipe, Pd or AuPd precursor solutions, MO/MWCNTs suspension in EG or DI water, and adding $\mathrm{KOH}$ to adjust $\mathrm{pH}$ to 12 , was prepared and encountered an exposure experiment for 8 minutes. The X-ray irradiation experiments were performed at the beamline $01 \mathrm{~A}$ in National Synchrotron Radiation Research Center (NSRRC), Hsinchu, Taiwan. The parameters of storage ring were $1.5 \mathrm{GeV}$ and $200 \mathrm{~mA}$. Un-monochromatic "white" X-ray beam was utilized throughout the exposure. The following filtering, drying and annealing procedures were same as above. The prepared catalysts were denoted as $\mathrm{Pd} / \mathrm{MO} / \mathrm{MWCNTs}(1 \mathrm{~A})$ or $\mathrm{AuPd} / \mathrm{MO} / \mathrm{MWCNTs}$ (1A) for those in DI aqueous solution. For those prepared via X-ray in ethylene glycol, the term (EG) was used. The prepared catalysts were denoted as Pd/MO/MWCNTs (1A) or Pd/MO/MWCNTs (EG).

The synthesis flow chart is shown in Fig. 1. 


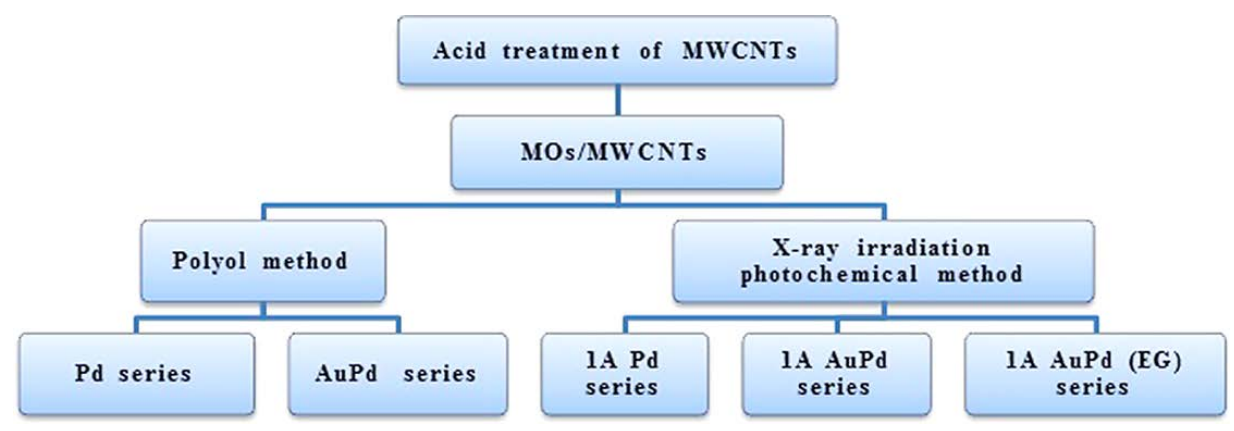

Fig. 1 The synthesis flowchart diagram.
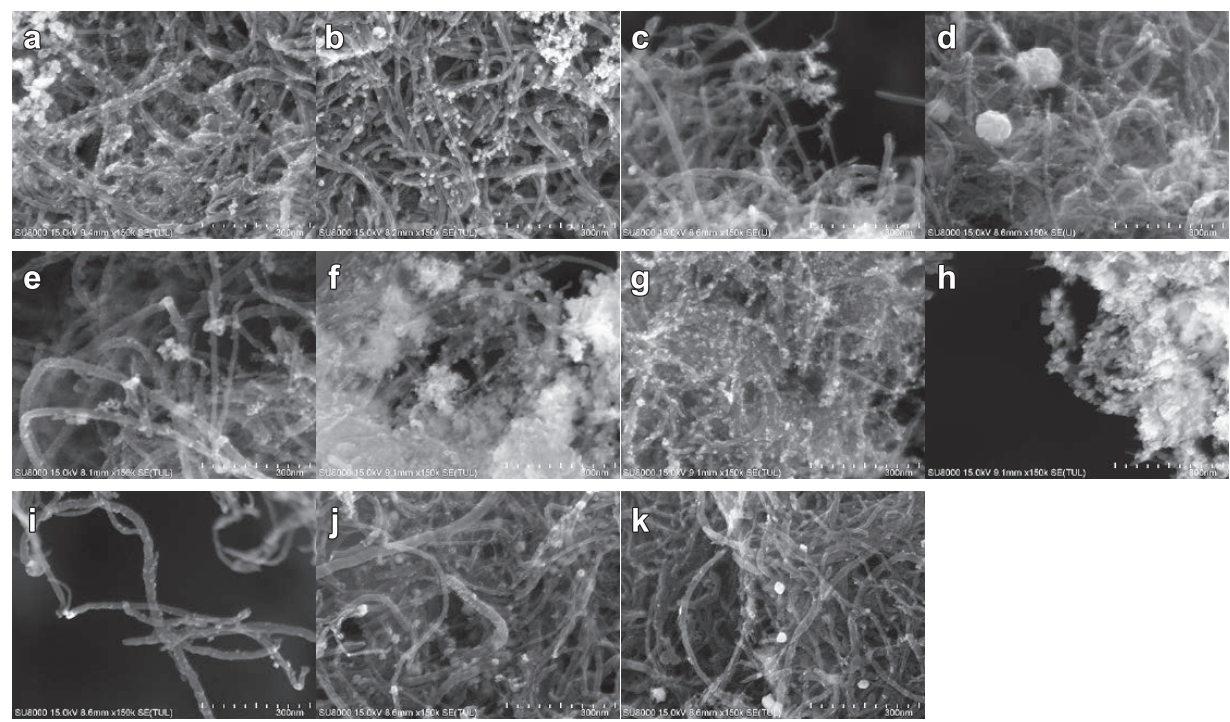

Fig. 2 FESEM images of (a) $\mathrm{Pd} / \mathrm{CeO}_{2} / \mathrm{MWCNTs}$, (b) AuPd/CeO $/ \mathrm{MWCNTs}$, (c) $\mathrm{AuPd} / \mathrm{Ru}_{\mathrm{x}} \mathrm{Ce}_{1-\mathrm{x}} \mathrm{O}_{2} / \mathrm{MWCNTs}$, and (d) $\mathrm{AuPd} / \mathrm{Ir}_{\mathrm{x}} \mathrm{Ce} \mathrm{e}_{1-\mathrm{x}} \mathrm{O}_{2} / \mathrm{MWCNTs}$ by polyol

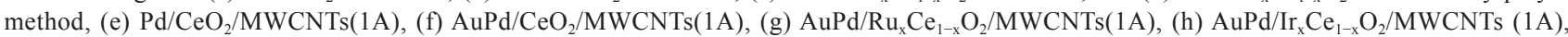
(i) $\mathrm{AuPd} / \mathrm{CeO}_{2} / \mathrm{MWCNTs}\left(1 \mathrm{~A}\right.$ ) (EG), (i) $\mathrm{AuPd} / \mathrm{Ru}_{\mathrm{x}} \mathrm{Ce}_{1-\mathrm{x}} \mathrm{O}_{2} / \mathrm{MWCNTs}(1 \mathrm{~A})$ (EG), and (k) AuPd/Ir $\mathrm{Ce}_{1-\mathrm{x}} \mathrm{O}_{2} / \mathrm{MWCNTs}$ (1A) (EG) by X-ray irradiation method.

Characterization and electrocatalytic performance: After the preparation, X-ray diffraction (XRD, MAC MXP 18, Cu Ka line, $\lambda=1.542 \AA$ ), field emission scanning electron microscope (FESEM, Hitachi SU8000 Series UHR Cold-Emission Field Emission Scanning Electron Microscope), high resolution transmission electron microscope (HRTEM, JEOL ARM200F Spherical Aberration Corrected Scanning Transmission Electron Microscope), and inductively coupled plasma optical emission spectrometry (ICP-OES, Perkin Elmer Optima-2000 DV) were applied to characterize the structure, morphology, and composition of the hybrid nanoparticles. The electrocatalytic performance of the Pd based catalysts can be evaluated by cyclic voltammetry $(\mathrm{CV})$ experimental which is conducted in a three-electrode system and CHI Model 6081C potential/ galvanostat instrument. The paste for the working electrode can be composed as $5 \mathrm{mg}$ sample, $0.05 \mathrm{~mL} 5 \%$ Nafion solution (DuPont Fluoroproduct, DE-2021), $5 \mathrm{mg}$ carbon black (Vulcan XC-72), and $5 \mathrm{~mL}$ ethanol. The well mixed paste is drop onto a glassy carbon disc (Toyo Tanso, IG-45, $9.0 \mu \Omega \mathrm{m}$ ) and dried in $85^{\circ} \mathrm{C}$. In the experiment, $\mathrm{Ag} / \mathrm{AgCl}$ is the reference electrode, and a $\mathrm{Pt}$ net is the counter electrode. A mixture of $3 \mathrm{M}$ formic acid and $1 \mathrm{M}$ sulfuric acid is the electrolyte as simulating the catalyst performance in DFAFCs. Only $1 \mathrm{M}$ sulfuric acid is used for the measurement of electrochemical surface area (ECSA). The scan range is from -0.2 to $1.0 \mathrm{~V}$ with scan rate $10 \mathrm{mV} / \mathrm{sec}$. The measured current (A) will be normalized by the Pd weight of the sample which has the Pd weight percent determined by Perkin Elmer Optima-2000 DV Inductively Coupled Plasma-Optical Emission Spectrometer (ICP-OES).

\section{Results and Discussion}

The morphologies of the hybrid nanoparticles are shown in Fig. 2. The particle size and size distribution were observed by bright field images. Energy Dispersive Spectroscopy on the FESEM had been conducted to recognize the composition of the nanoparticles but not showed the data here. In the FESEM images of the fig. 2 (a) to 2 (d) for the samples synthesized by polyol process, AuPd particles with various sizes decorated on the MWCNTs surfaces modified by $\mathrm{Ir}$ or $\mathrm{Ru}$ doped $\mathrm{CeO}_{2}$. The largest $\mathrm{AuPd} / / \mathrm{Ir}_{\mathrm{x}} \mathrm{CeO}_{2-\mathrm{x}} /$ MWCNTs particles may be more than $100 \mathrm{~nm}$ in diameter. But Pd or AuPd particles, as coated on $\mathrm{CeO}_{2}$ modified MWCNTs, disperse better and have more uniform particle size less than $10 \mathrm{~nm}$. The figures 
of 2 (e) to $2(\mathrm{k})$ indicate the FESEM images of samples that Pd or AuPd synthesized by X-ray irradiation method in DI water or EG. In the case of EG condition, Pd or AuPd cannot well deposit on the surface of substrates and have the large particle size. While in the case of DI water, Pd or AuPd are homogenously deposit on the surface of substrates except in Ir doped sample. To observe more detail of these structures, TEM and HRTEM are used in this study. The samples of $\mathrm{Pd} / \mathrm{CeO}_{2} / \mathrm{MWCNTs}, \mathrm{AuPd} / \mathrm{Ru}_{\mathrm{x}} \mathrm{Ce}_{1-\mathrm{x}} \mathrm{O}_{2} / \mathrm{MWCNTs}$, $\mathrm{AuPd} / \mathrm{Ru}_{\mathrm{x}} \mathrm{Ce}_{1-\mathrm{x}} \mathrm{O}_{2} / \mathrm{MWCNTs}(1 \mathrm{~A})$ are choose to observe the detail TEM images as shown in Fig. 3. The images indicate the metals or metal oxides are deposited on the surface of MWCNTs with well dispersion. For HRTEM images of previous samples, the white circle area in Fig. 3 are enlarge to observed the atom resolution as showed in Fig. 4. In Fig. 4 (a), $\mathrm{Pd}$ in $\mathrm{Pd} / \mathrm{CeO}_{2} / \mathrm{MWCNTs}$ can be recognized by analyzing the fringe patterns, and reveal its particle size about 3-4 nm. HRTEM images in the figures of 4 (b) and 4 (c) show the AuPd samples of $\mathrm{Ru}_{\mathrm{x}} \mathrm{Ce}_{1-\mathrm{x}} \mathrm{O}_{2} / \mathrm{MWCNTs}$ and $\mathrm{Ru}_{\mathrm{x}} \mathrm{Ce}_{1-\mathrm{x}} \mathrm{O}_{2} /$ MWCNTs (1A). There are fringes with d-space about $0.23 \mathrm{~nm}$ which are a little large than that of Pd (111) in Fig. 4 (a) and recognized as Au-Pd (111) solid solution phase. The particle size of $\mathrm{AuPd}$ on $\mathrm{Ru}_{\mathrm{x}} \mathrm{Ce}_{1-\mathrm{x}} \mathrm{O}_{2} / \mathrm{MWCNTs}(1 \mathrm{~A})$ is about $5 \mathrm{~nm}$ and larger on $\mathrm{Ru}_{\mathrm{x}} \mathrm{Ce}_{1-\mathrm{x}} \mathrm{O}_{2} / \mathrm{MWCNTs}$. $\mathrm{CeO}_{2}$ particles with different crystalline directions also can be found with particle size about 3-7 nm. The Ir or Ru doping effect cannot be observed in the images, for their amounts are too little. All these images show that the particles are also decorated on the surface of MWCNTs. These morphologies show the nanoparticles can be successfully synthesized and dispersed well on MO/MWCNTs.

ICP-OES analysis results show that the doped amounts of Ru and $\mathrm{Ir}$ are $0.03 \mathrm{wt} \%-0.05 \mathrm{wt} \%$. It confirms the existence of the two doped metals. XRD patterns in Fig. 5 (a), for $\mathrm{Ru}_{\mathrm{x}} \mathrm{Ce}_{1-\mathrm{x}} \mathrm{O}_{2} /$ MWCNTs and $\mathrm{Ir}_{\mathrm{x}} \mathrm{Ce}_{1-\mathrm{x}} \mathrm{O}_{2} /$ MWCNTs, the locations of peaks are the same as $\mathrm{CeO}_{2} / \mathrm{MWCNTs}$, because the amounts of doped metals were extremely small. The lattice constant and particle size of metal oxide supported on MWCNTs can be evaluated by using the XRD data. The evaluated averaged particle sizes of different metal oxides are about $4.1-8.3 \mathrm{~nm}$. Ceria is a well-known oxygen storage material, the lattice constant may change by the situation of oxygen storage. As Ru or Ir doping, the structure may be fixed by the Ru or Ir atoms. In comparison to the $5.4257 \AA$ for Ru doping one and $5.4597 \AA$ for Ir doping one, the average lattice constant of un-doped $\mathrm{CeO}_{2}$ is the smallest (5.4214 $\AA$ ), which means the doped metals substituted oxygen and located at oxygen sites or interstitial sites because of the radius of the elements $\mathrm{Ce}>\mathrm{Ir}>\mathrm{Ru}>\mathrm{O}$. In Fig. 5 (b), the XRD patterns of three Pd/MO/MWCNTs samples have no structure difference. The peaks positions of $\mathrm{CeO}_{2}$ are not shifted by the doping of Ir or Ru. In figures 5 (c) to 5 (e), the observation is focused on the formation of Au-Pd solid solution. In Fig. 5 (c), AuPd/MWCNTs (black curve) more approach AuPd solid solution. But it's obviously to find two peaks, combining or not,

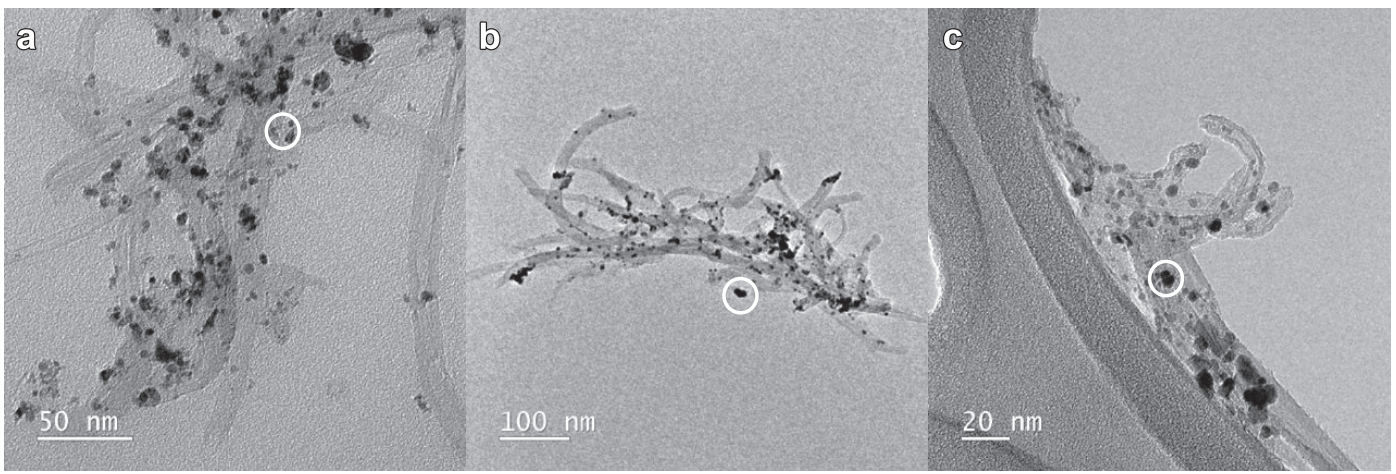

Fig. 3 TEM images of (a) $\mathrm{Pd} / \mathrm{CeO}_{2} / \mathrm{MWCNTs}$, (b) AuPd/Ru $\mathrm{Ru}_{\mathrm{x}} \mathrm{Ce}_{1-\mathrm{x}} \mathrm{O}_{2} / \mathrm{MWCNTs}$ by polyol method, and (c) $\mathrm{AuPd} / \mathrm{Ru}_{\mathrm{x}} \mathrm{Ce} \mathrm{e}_{1-\mathrm{x}} \mathrm{O}_{2} / \mathrm{MWCNTs}$ (1A) by X-ray irradiation photochemical method.

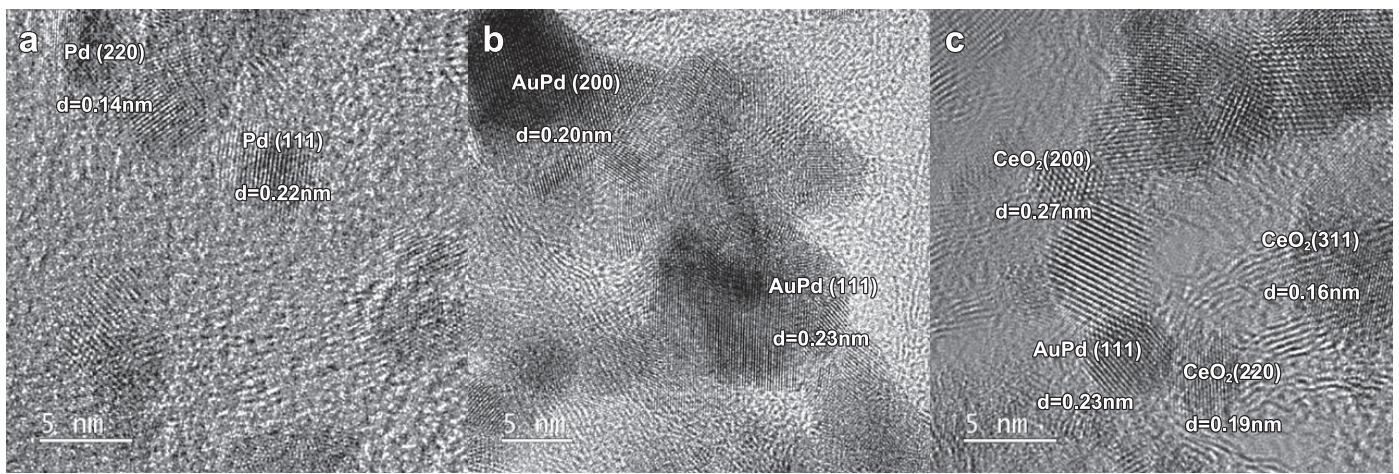

Fig. 4 HRTEM images of (a) Pd/CeO $/$ MWCNTs, (b) AuPd/ $\mathrm{Ru}_{\mathrm{x}} \mathrm{Ce}_{1-\mathrm{x}} \mathrm{O}_{2} / \mathrm{MWCNTs}$ by polyol method, and (c) AuPd/Ru $\mathrm{Re}_{\mathrm{x}} \mathrm{Ce}_{1-\mathrm{x}} \mathrm{O}_{2} / \mathrm{MWCNTs}$ (1A) by X-ray irradiation photochemical method. 
(a)

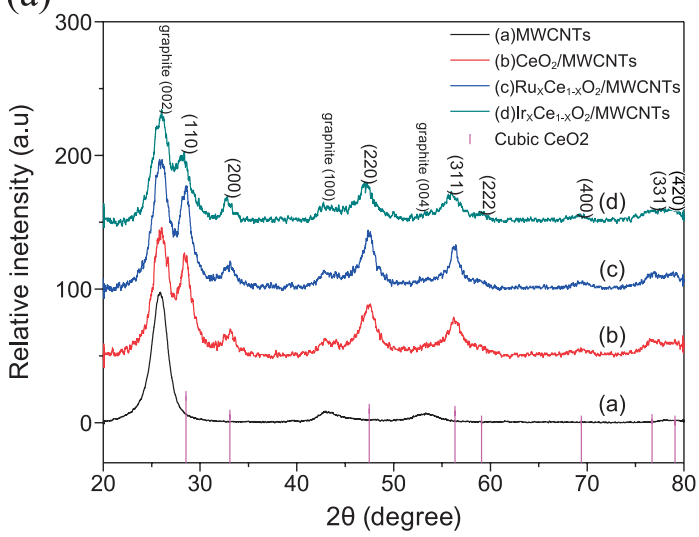

(c)

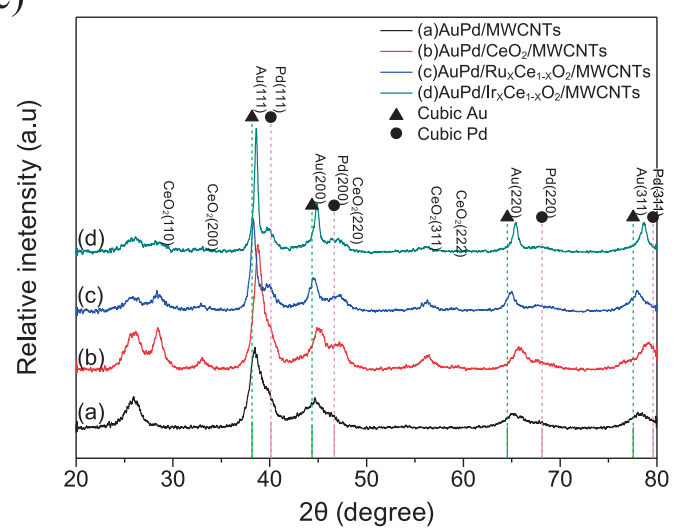

(e)

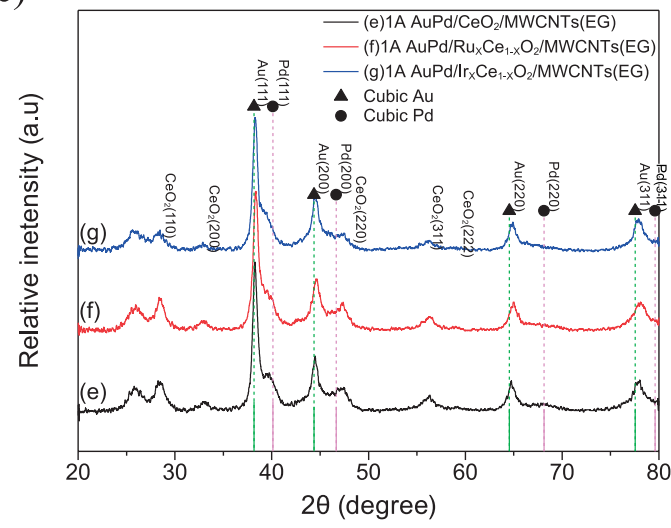

(b)

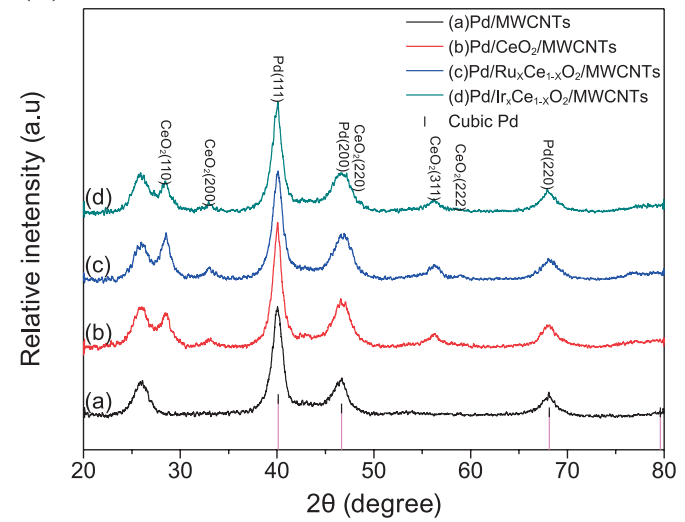

(d)

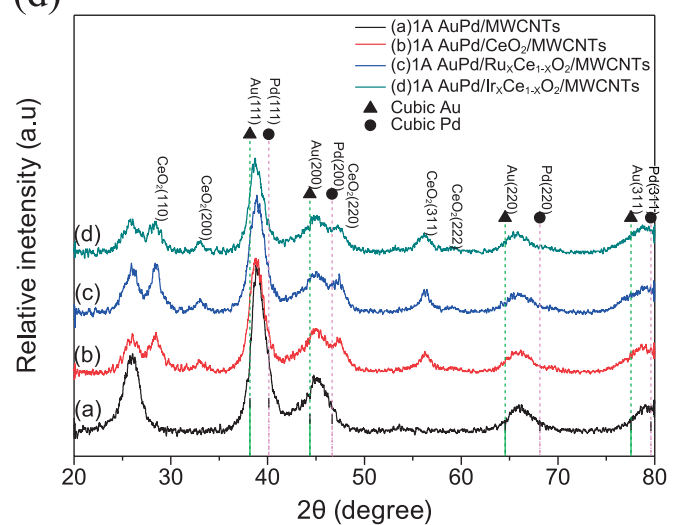

Fig. 5 XRD patterns of (a) Pd/MO/MWCNTs, (b) AuPd/MO/MWCNTs, (c) AuPd/MO/MWCNTs (1A) in DI water, and (d) AuPd/MO/MWCNTs (1A) in EG.

between pure $\mathrm{Au}$ and $\mathrm{Pd}$ positions. It means, as preparing by polyol method, one Au-rich AuPd and one Pd-rich AuPd were formed, not only for decorating on MWCNTs but also for $\mathrm{CeO}_{2} / \mathrm{MWCNTs}$, $\mathrm{Ru}_{\mathrm{x}} \mathrm{Ce}_{1-\mathrm{x}} \mathrm{O}_{2} / \mathrm{MWCNTs}$ and $\mathrm{Ir}_{\mathrm{x}} \mathrm{Ce}_{1-\mathrm{x}} \mathrm{O}_{2} /$ MWCNTs. As AuPd/MO/ MWCNTs preparing by X-ray irradiation, the solvent system changed the structure of the metal catalysts. In Fig. 5 (d), AuPd solid solution single phase was successfully formed on different substrates in DI water. But two solution phases were formed in EG (ethylene glycol), Fig. 5 (e). The AuPd series nanocatalysts synthesized via X-ray irradiation in DI water will be expected to have better electrocatalytic performance than those via polyol method or irradiation in EG.
The prepared catalysts were conducted the ECSA measurement in sulfuric acid solution. The results are shown in Table $1 . \mathrm{Pd} / \mathrm{CeO}_{2} /$ MWCNTs can perform best in formic acid for it has the best ECSA $370.43 \mathrm{~m}^{2} / \mathrm{g}$ Pd. For AuPd series, though those AuPd prepared by irradiation can form single solid solution phase, and lower the ECSA values. It may imply the X-ray preparation for AuPd will not promising electrocatalyst with high performance.

The electrocatalytic performance of the prepared catalysts was evaluated by $\mathrm{CV}$ test in a $1 \mathrm{M} \mathrm{H}_{2} \mathrm{SO}_{4}$ and $3 \mathrm{M}$ formic acid mixture electrolyte solution. The maximum current density of $\mathrm{CV}$ curves for different catalysts were compared in Fig. 6. In Fig. 6 (a), $\mathrm{Pd} / \mathrm{CeO}_{2} / \mathrm{MWCNTs}$ have the best current density. The result is 
Table 1 ECSA data of the Pd based catalysts synthesized via different methods.

\begin{tabular}{cccc}
\hline ECSA $\left(\mathrm{m}^{2} / \mathrm{g}\right.$ Pd $)$ & $\begin{array}{c}\text { Polyol } \\
\text { method }\end{array}$ & $\begin{array}{c}\text { X-ray } \\
\text { irradiation } \\
\text { (DI) }\end{array}$ & $\begin{array}{c}\text { X-ray } \\
\text { irradiation } \\
(\mathrm{EG})\end{array}$ \\
\hline $\mathrm{Pd} / \mathrm{MWCNTs}$ & 89.64 & 159.27 & - \\
$\mathrm{Pd} / \mathrm{CeO}_{2} / \mathrm{MWCNTs}$ & 370.43 & 140.26 & - \\
$\mathrm{Pd} / \mathrm{Ru}_{\mathrm{x}} \mathrm{Ce}_{1-\mathrm{x}} \mathrm{O}_{2} / \mathrm{MWCNTs}$ & 151.73 & 69.43 & - \\
$\mathrm{Pd} / \mathrm{Ir}_{\mathrm{x}} \mathrm{Ce}_{1-\mathrm{x}} \mathrm{O}_{2} / \mathrm{MWCNTs}$ & 46.55 & 95.55 & - \\
$\mathrm{AuPd} / \mathrm{MWCNTs}$ & 66.69 & 55.35 & - \\
$\mathrm{AuPd} / \mathrm{CeO}_{2} / \mathrm{MWCNTs}$ & 30.57 & 56.23 & 79.97 \\
$\mathrm{AuPd} / \mathrm{Ru}_{\mathrm{x}} \mathrm{Ce}_{1-\mathrm{x}} \mathrm{O}_{2} / \mathrm{MWCNTs}$ & 145.13 & 70.04 & 77.57 \\
$\mathrm{AuPd} / \mathrm{Ir}_{\mathrm{x}} \mathrm{Ce}_{1-\mathrm{x}} \mathrm{O}_{2} / \mathrm{MWCNTs}$ & 104.27 & 29.5 & 45.82 \\
\hline
\end{tabular}

consistent to our previous study about Pt supported on $\mathrm{CeO}_{2}$ modified MWCNTs ${ }^{23}$. The modification of $\mathrm{CeO}_{2}$ can help the metal catalyst to prevent $\mathrm{CO}$ poisoning and promote the electrocatalytic ability. While the doping of $\mathrm{Ir}$ or $\mathrm{Ru}$ in $\mathrm{CeO}_{2}$ doesn't enhance but lower the catalyst activity. The electrocatalytic activities of $\mathrm{Pd} / \mathrm{Ir}_{\mathrm{x}} \mathrm{CeO}_{2-\mathrm{x}} / \mathrm{MWCNTs}$ and $\mathrm{Pd} / \mathrm{Ru}_{\mathrm{x}} \mathrm{CeO}_{2-\mathrm{x}} / \mathrm{MWCNTs}$ are worse than that of Pd/MWCNTs. There are two oxidation peaks in MO modified MWCNTs samples that may indicate formic acid will oxidize in different mechanisms. It may limit the applied voltage to be higher than $0.3 \mathrm{~V}$ in fuel cells.

In Fig. 6 (b), AuPd series catalysts prepared by polyol method, the performance order is that $\mathrm{AuPd} / \mathrm{Ru}_{\mathrm{x}} \mathrm{Ce}_{1-\mathrm{x}} \mathrm{O}_{2} / \mathrm{MWCNTs}>\mathrm{AuPd} /$

(a)

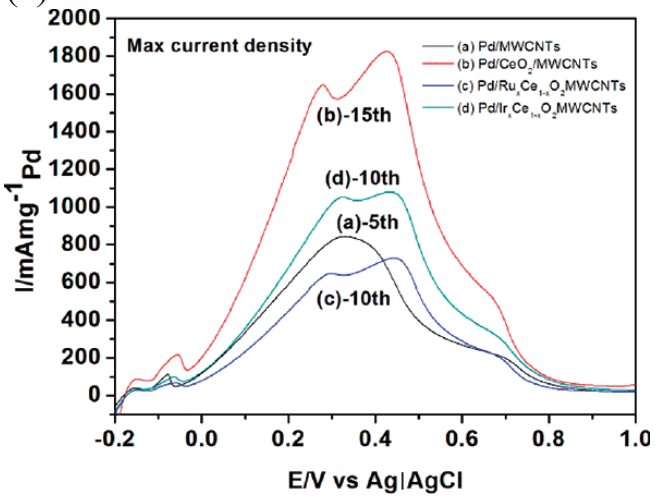

(c)

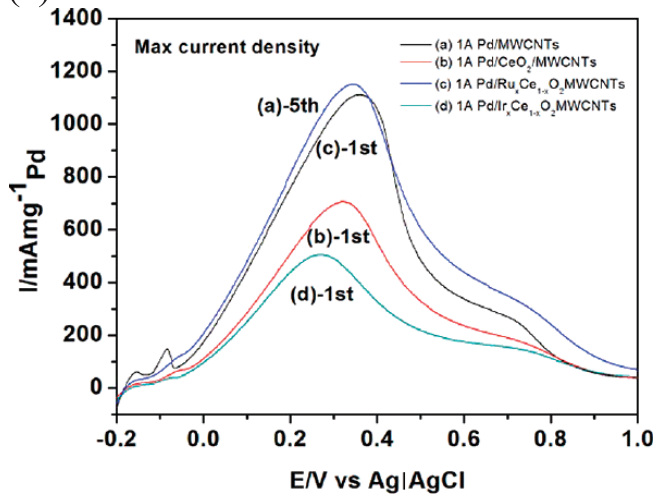

MWCNTs $>\mathrm{AuPd} / \mathrm{Ir}_{\mathrm{x}} \mathrm{Ce}_{1-\mathrm{x}} \mathrm{O}_{2} / \mathrm{MWCNTs}>\mathrm{AuPd} / \mathrm{CeO}_{2} / \mathrm{MWCNTs}$. The modification of $\mathrm{Ru}_{\mathrm{x}} \mathrm{Ce}_{1-\mathrm{x}} \mathrm{O}_{2}$ can promote AuPd catalyzing ability most. The results of the figures 6 (c) and 6 (d) indicate the CV performances of the metal catalysts prepared by X-ray irradiation. $\mathrm{Pd} / \mathrm{MWCNTs}(1 \mathrm{~A})$ has the best performances comparing to those in MO/MWCNTs systems. This result is consistent to the ECSA result: Pd/MWCNTs prepared by photosynthesis has better ECSA value up to $159.27 \mathrm{~m}^{2} / \mathrm{g} \mathrm{Pd}$, while the performance of AuPd prepared by X-ray is not as good as the expectation. But, AuPd/MWCNTs have the best electrocatalytic performance in AuPd series by X-ray irradiation. In general, for the corresponding I-V curves in (a) and (b), the two polyol results, are better than those in (c) and (d), the two X-ray irradiation results, Pd based catalysts prepared by polyol method show the better electrocatalytic performance.

The long term stability of the catalysts was evaluated in a $1 \mathrm{M}$ $\mathrm{H}_{2} \mathrm{SO}_{4}$ and $3 \mathrm{M}$ formic acid mixture electrolyte solution under $0.3 \mathrm{~V}$ as showed in Fig. 7. For polyol samples in Pd series (Fig. 7 (a)), Pd/ $\mathrm{CeO}_{2}$ /MWCNTs have the highest stability up to $10 \mathrm{k}$ seconds with current density of $250 \mathrm{~mA} / \mathrm{mg}$ Pd. For AuPd series in Fig. 7 (b), all samples show stable up to $10 \mathrm{k}$ second except that of Ir doped one. But the current density about $100 \mathrm{~mA} / \mathrm{mg} \mathrm{Pd}$ is much lower than those of Pd series samples. In the case of samples prepared by X-ray irradiation, Pd/MWCNTs (1A) has the best stability in $\mathrm{Pd}$ (1A) series samples only retaining a little bit higher than $50 \mathrm{~mA} / \mathrm{mg} \mathrm{Pd}$ current as showed in Fig. 7 (c). Fig. 7 (d) indicates the I-t curve of

(b)

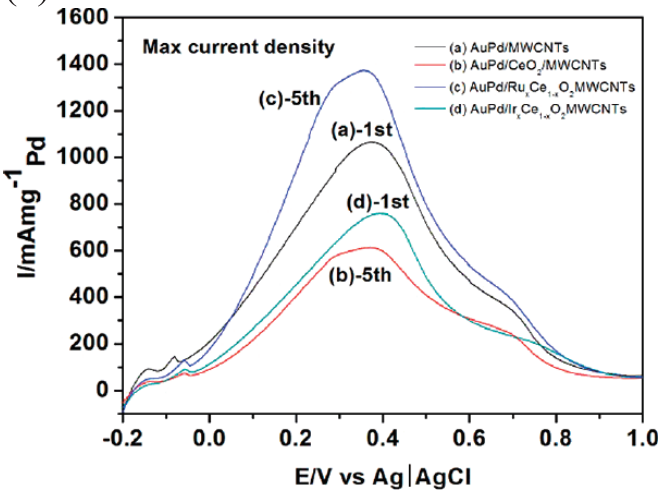

(d)

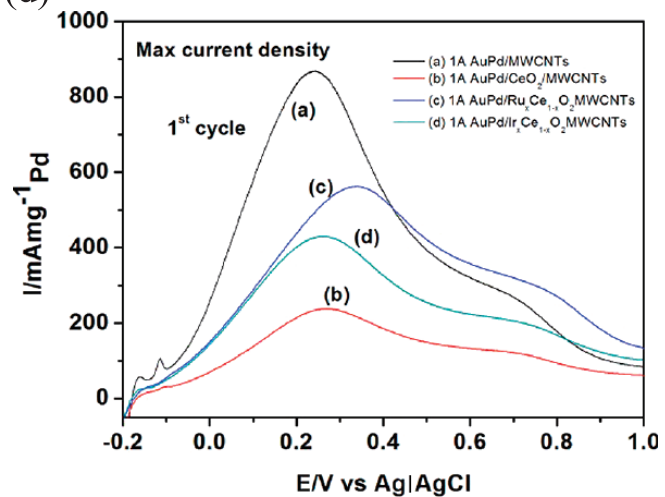

Fig. 6 The maximum current density of CV curves of (a) Pd series and (b) AuPd series catalysts prepared by polyol method, (c) Pd series and (d) AuPd series catalysts prepared by X-ray irradiation in DI water. 
(a)

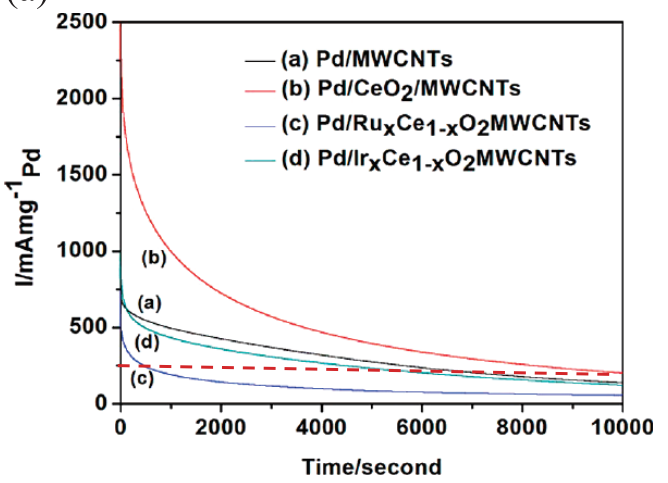

(c)

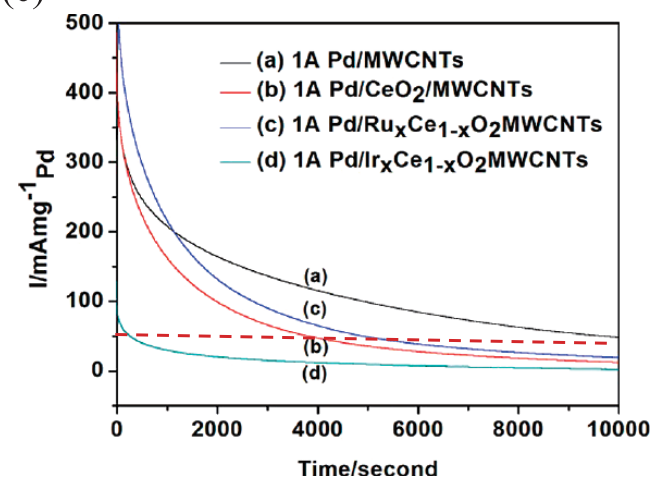

(b)

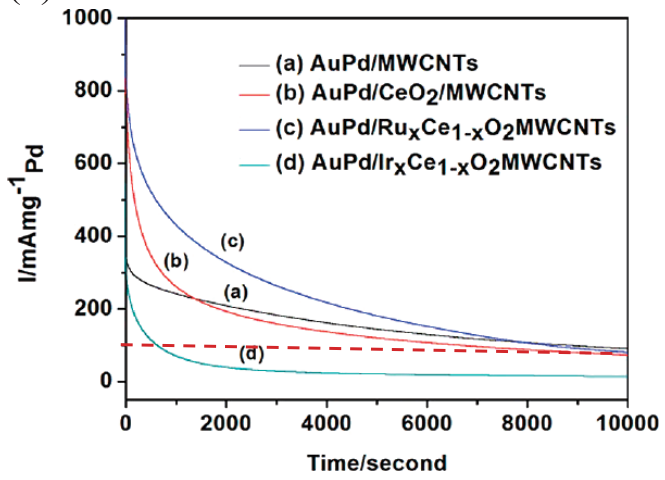

(d)

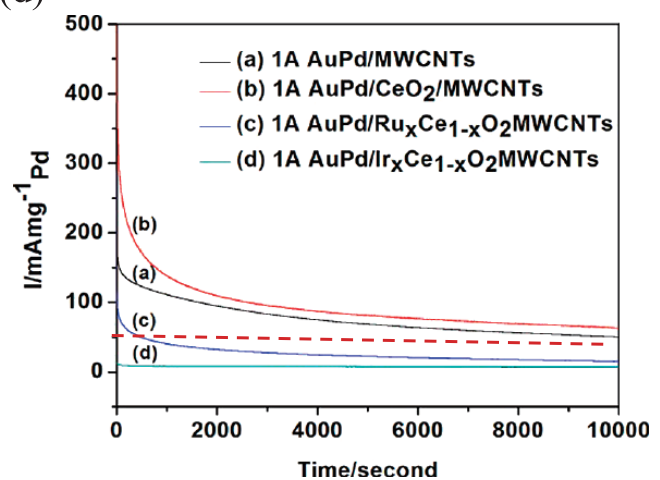

Fig. 7 I-t curves, in $1 \mathrm{M} \mathrm{H}_{2} \mathrm{SO}_{4}$ and $3 \mathrm{M}$ formic acid under $0.3 \mathrm{~V}$, of the catalysts prepared by polyol and X-ray irradiation photochemical methods.

AuPd (1A) series samples. The results above indicate Pd/MWCNTs (1A) and $\mathrm{Pd} / \mathrm{CeO}_{2} / \mathrm{MWCNTs}(1 \mathrm{~A})$ have good stability and retain more than $60 \mathrm{~mA} / \mathrm{mg}$ Pd current density that is better than that of $\operatorname{Pd}(1 \mathrm{~A})$ series.

\section{Summary}

A precipitation method was used to synthesize $\mathrm{CeO}_{2}, \mathrm{Ru}_{\mathrm{x}} \mathrm{CeO}_{2-\mathrm{x}}$, and $\mathrm{Ir}_{\mathrm{x}} \mathrm{CeO}_{2-\mathrm{x}}$ on acid treated MWCNTs in this study. Then polyol and X-ray irradiation were introduced to decorate $\mathrm{Pd}$ or AuPd on the prepared MO/MWCNTs or MWCNTs. The HRTEM images confirmed the existence of the hybrid nanoparticles. The nanoparticles can disperse well with particle size about 5-10 nm. But the $\mathrm{Pd}$ nanoparticles in $\mathrm{Pd} / \mathrm{Ir}_{\mathrm{x}} \mathrm{CeO}_{2-\mathrm{x}} / \mathrm{MWCNTs}$ can aggregate to about $100 \mathrm{~nm}$. As analyzing XRD patterns, Au and Pd form two solid solution phases via polyol method or irradiation in EG, but they form a single solid solution phase via X-ray irradiation in DI water. $\mathrm{AuPd} / \mathrm{Ru}_{\mathrm{x}} \mathrm{CeO}_{2-\mathrm{x}} / \mathrm{MWCNTs}$ prepared by polyol method can oxidize formic acid directly with highest current density of $1258.3 \mathrm{~mA} / \mathrm{mg} \mathrm{Pd}$ and $\mathrm{Pd} / \mathrm{CeO}_{2} / \mathrm{MWCNTs}$ have a best stability than all the other catalysts.

\section{References}

1) S. Ha, B. Adams, R. I. Masel: "A miniature air breathing direct formic acid fuel cell", Journal of Power Sources, 128 (2004) 119-124.

2) X. Yu, P. G. Pickup: "Recent advances in direct formic acid fuel cells (DFAFC)", Journal of Power Sources, 182 (2008) 124-132.

3) X. Wang, J. M. Hu, I. M. Hsing: "Electrochemical investigation of formic acid electro-oxidation and its crossover through a Nafion ${ }^{\circledR}$ membrane", Journal of Electroanalytical Chemistry, 562 (2004) 73-80

4) Y. W. Rhee, S. Y. Ha, R. I. Masel: "Crossover of formic acid through Nafion ${ }^{\circledR}$ membranes”, Journal of Power Sources, 117 (2003) 35-38.

5) N. Hoshi, K. Kida, M. Nakamura, M. Nakada, K. Osada "Structural Effects of Electrochemical Oxidation of Formic Acid on Single Crystal Electrodes of Palladium", J. Phys. Chem. B, 110 (2006) 12480-12484.

6) R. Larsen, J. Zakzeski, R. I. Masel: "Unexpected Activity of Palladium on Vanadia Catalysts for Formic Acid Electrooxidation", Electrochemical and Solid-State Letters, 8 (2005) A291-A293.

7) H. Lee, S. E. Habas, G. A. Somorjai, P. Yang: "Localized Pd Overgrowth on Cubic Pt Nanocrystals for Enhanced Electrocatalytic Oxidation of Formic Acid", J. Am. Chem. Soc., 130 (2008) 5406-5407.

8) M. H. Shao, K. Sasaki, R. R. Adzic: "Pd-Fe Nanoparticles as Electrocatalysts for Oxygen Reduction", J. Am. Chem. Soc., 128 (2006) 3526-3527.

9) Y. J. Chiou, K. Y. Chen, H. M. Lin, W. J. Liou, H. W. Liou, S. H. Wu, A. Mikolajczuk, M. Mazurkiewicz, A. Malolepszy, 
L. Stobinski, A. Borodzinski: "Electrocatalytic properties of hybrid palladium-gold/multi-walled carbon nanotube materials in fuel cell applications", Phys. Status Solidi A, 208 (2011) 1778-1782.

10) P. Mars, D. W. Van Krevelen: "Oxidations carried out by means of vanadium oxide catalysts", Special Supplement to Chemical Engineering Science, 3 (1954) 41.

11) M. Gotz, H. Wendt: "Binary and ternary anode catalyst formulations including the elements W, Sn and Mo for PEMFCs operated on methanol or reformate gas", Electrochimica Acta, 43 (1998) 3637-3644.

12) A. F. Diwell, R. R. Rajaram, H. A. Shaw, T. J. Truex: Catalysis and Automotive Pollution Control II (1991) 139.

13) M. Ozawa, M. Kimura: "Effect of cerium addition on the thermal stability of gamma alumina support", Journal of Materials Science Letters, 9 (1990) 291-293.

14) M. A. Shalab: "Kinetic modeling of $\mathrm{CO}$ oxidation on $\mathrm{Pt} / \mathrm{CeO}_{2}$ in a gradientless reactor", Journal of Chemical Technology and Biotechnology, 65 (1996) 317-324.

15) J. W. Long, R. M. Stroud, K. E. Swider-Lyons, D. R. Rolison: "How To Make Electrocatalysts More Active for Direct Methanol OxidationAvoid PtRu Bimetallic Alloys!”, J. Phys. Chem. B, 104 (2000) 9772-9776.

16) R. Gómez, M. J. Weaver: "Electrochemical Infrared Studies of Monocrystalline Iridium Surfaces. 3. Adsorbed Nitric Oxide and Carbon Monoxide as Probes of $\operatorname{Ir}(100)$ Interfacial Structure", J. Phys. Chem. B, 102 (1998) 3754-3764.

17) J. C. Frost: "Junction effect interactions in methanol synthesis catalysts", Nature, 334 (1988) 577-580.

18) S. E. Golunski, H. A. Hatcher, R. R. Rajaram, T. J. Truex: "Origins of low-temperature three-way activity in $\mathrm{Pt} / \mathrm{CeO}_{2}$ ", Applied Catalysis B: Environmental, 5 (1995) 367-376.
19) S. Deshpande, S. Patil, S. Kuchibhatla, S. Sea: "Size dependency variation in lattice parameter and valency states in nanocrystalline cerium oxide", Applied Physics Letters, 87 (2005) 133113-1-3.

20) S. Scire, S. Minico, C. Crisafulli, C. Satriano, A. Pistone: "Catalytic combustion of volatile organic compounds on gold/cerium oxide catalysts", Applied Catalysis B: Environmental, 40 (2003) 43-49.

21) B. C. H. Steele, A. Heinzel: "Materials for fuel-cell technologies", Nature, 414 (2001) 345-352.

22) R. W. Schutz: "Ruthenium Enhanced Titanium Alloys", Platinum Metals Review, 40 (1996) 54-61.

23) T. Ioroi, K. Yasuda: "Platinum-Iridium Alloys as Oxygen Reduction Electrocatalysts for Polymer Electrolyte Fuel Cells", J. Electrochemical Society, 152 (2005) A1917-A1924.

24) H. Tsaprailis, V. I. Birss: "Sol-Gel Derived Pt-Ir Mixed Catalysts for DMFC Applications", Electrochemical and Solid-State Letters, 7 (2004) A348-A352.

25) C. H. Chen, Y. J. Chiou, W. J. Liou, W. S. Lin, H. M. Lin, S. H. Wu, A. Borodziński, P. Kedzierzawski, L. Stobinski, S. H. Chien : "Synthesis and Electrocatalysis Application of Hybrid Platinum/Cerium Oxide/Multi-Walled Carbon Nanotubes", Functional Materials Letters, 3 (2011) 295-298.

26) Y. J. Chiou, H. J. Hsu, H. M. Lin, W. J. Liou, H. W. Liou, S. H. Wu, S. H. Chien: "Synthesis and characterization of $\mathrm{Cu}-\mathrm{Pt} / \mathrm{MWCNT}$ for use in electrocatalytic applications", Particuology, 9 (2011) 522-527.

27) K. N. Lin, W. J. Liou, H. M. Lin, T. Y. Yang, C. K. Lin: "Structural Investigations of Hybrid $\mathrm{TiO}_{2} / \mathrm{CNTs}$ Nanomaterials", Journal of Nanoscience and Nanotechnology, 10 (2010) 3155 3161. 